Uşak Üniversitesi Sosyal Bilimler Dergisi

$2013,6 / 4$

T. ÇALIK, S. KOŞAR, A. Ç. KILINÇ, E. ER

\title{
İlköğretim Okulu Öğretmenlerinin Değişime Direnme Davranışları ile Öz Yeterlikleri Arasındaki İlişki
}

\author{
Temel ÇALIK \\ Serkan KOŞAR ${ }^{* *}$ \\ Ali Çağatay KILINÇ⿻ \\ Emre ER ${ }^{* * * * *}$
}

\section{Özet}

$\mathrm{Bu}$ araştırmanın amacı ilköğretim okulu öğretmenlerinin değişime direnme davranışları ile öz yeterlik düzeyleri arasındaki ilişkilerin incelenmesidir. Araştırma ilişkisel tarama modelinde kurgulanmıştır. Araştırmanın örneklemini Ankara il merkezinde bulunan 14 ilköğretim okulunda görev yapan 415 öğretmen oluşturmaktadır. Araştırma verileri “Değişime Direnme Ölçeği" ve "Öğretmen Öz Yeterlik Ölçeği" aracılığıyla toplanmıştır. Verilerin analizinde Pearson Momentler Çarpımı Korelasyon Katsayısı ve çoklu doğrusal regresyon analizinden yararlanılmıştır. Araştırma sonuçları değişime direnmenin öğretmen öz yeterliğinin tüm alt boyutlarıyla negatif yönde ilişkili olduğunu göstermektedir. Bununla birlikte, öğretmen öz yeterliğinin alt boyutları arasında pozitif yönlü ilişkiler tespit edilmiştir. Ayrıca, regresyon analizi sonuçları öğretmen öz yeterliğinin her üç boyutunun da değişime direnmenin anlamlı birer yordayıcısı olmadığı tespit edilmiştir.

Anahtar Sözcükler: İlköğretim okulu, öğretmen, değişime direnme, öz yeterlik

The Relationship Between Primary School Teachers' Resistance to Change Behaviors and Their Self-Efficacy

\footnotetext{
* Prof. Dr., Gazi Üniversitesi, Gazi Eğitim Fakültesi, Eğitim Bilimleri , Eğitim Yönetimi,Teftişi,Planlaması ve Ekonomisi

** Arş. Gör. Dr., Gazi Üniversitesi, Gazi Eğitim Fakültesi, Eğitim Bilimleri , Eğitim Yönetimi,Teftişi,Planlaması ve Ekonomisi

*** Arş. Gör. Dr., Gazi Üniversitesi, Gazi Eğitim Fakültesi, Eğitim Bilimleri , Eğitim Yönetimi,Teftişi,Planlaması ve Ekonomisi

***** Arş. Gör., Gazi Üniversitesi, Gazi Eğitim Fakültesi, Eğitim Bilimleri , Eğitim Yönetimi,Teftişi,Planlaması ve Ekonomisi
} 
Uşak Üniversitesi Sosyal Bilimler Dergisi

$2013,6 / 4$

T. ÇALIK, S. KOŞAR, A. Ç. KILINÇ, E. ER

\begin{abstract}
The purpose of this study was to examine the relationships between primary school teachers' resistance to change behaviors and their selfefficacy levels. The study employed relational search model. The population of the study consisted of 415 teachers employed in 14 primary schools in Ankara city center. Data was collected via "Resistance to Change Scale" and "Teacher Self-Efficacy Scale". Pearson Product-Moment Correlation Coefficients and standard multiple regression analysis were performed to analyze the data. Results indicated that all sub-scales of teacher self-efficacy were negatively correlated with resistance to change. It was also referred from the results that sub-scales of teacher self-efficacy were positively correlated with each other. Finally, regression analysis results mirrored resistance to change was not predicted significantly by any subscales of teacher self-efficacy.
\end{abstract}

Keywords: Primary school, teacher, resistance to change, selfefficacy

\title{
Giriş
}

Eğitimde değişim çalışmalarının başarısında değişime gösterilen direnç, kısa ve uzun dönemli değişim hedeflerinin belirlenmesi ve toplumun önemli bir kısmını doğrudan ilgilendiren sosyal süreci planlamanın getirdiği zorluklar belirleyici rol oynamaktadır (Fullan, 2007). Eğitimde değişimin merkezinde okulun yer aldığı ve değişim çabalarının özünde öğrenci başarısının artırılmasının amaçlandığı düşünüldüğünde, öğretmenlerin etkili ve istekli olmalarının değişim sürecinin başarılı olmasında önemli olduğu düşünülmektedir.

Geçmişte örgütsel değişim planlanabilir ve kontrol edilebilir bir süreç olarak ele alınırken, günümüzde daha esnek bir biçimde yapılandırılarak işbaşında devam eden mesleki gelişimi sağlama ve uygulamaları iyileştirme şeklinde ifade edilmektedir (Burnes, 2009; Floyd, 2002; Fullan, 2007; Hargreaves ve Fullan, 1998; Hopkins, 2007; Seashore, 2009; Stickland, 1998; Wheatley, 2006). Bu bağlamda, değişimin uygulayıcısı konumundaki öğretmenlerin değişime yönelik algılarının alanyazında yoğun bir biçimde incelendiği ifade edilebilir (Akpınar ve Aydın, 2007; Banning, 1954; Cenker ve Akgül-Macaroğlu, 2011; Fullan, 1993; Hargreaves, 2005; Kennedy ve Kennedy, 1996; Zayim, 2010; Zimmerman, 2006).

Öğretmenlerin öz yeterlik düzeyleriyle değişime olan algıları arasında ilişki olduğu söylenebilir. Jerald (2007) öz yeterlik düzeyi yüksek olan 
öğretmenlerin yeni fikirlere açık olduklarını, öğrenci öğrenmesini artırmaya yönelik sınıf içi uygulamalarını sürekli olarak geliştirdiklerini, karşılaştıkları olumsuz durumlara yönelik çözümler üretebildiklerini ve öğrenme güçlüğü çeken öğrencilerle daha fazla ilgilendiklerini ileri sürmektedir. Bununla birlikte, öz yeterliği yüksek olan öğretmenlerin değişimi benimseme, öğretimi zenginleştirme ve yenilikçi öğretim teknikleri kullanma konusunda daha istekli oldukları söylenebilir (Allinder, 1994; Akt. Tschannen-Moran ve Hoy, 2001; Evers, Brouwers ve Tomic, 2002). Ayrica, Guskey (1987) öz yeterlik düzeyi yüksek olan öğretmenlerin, öğrencilerin başarılı olduğu kadar başarısız olduğu durumlarda da sorumluluk üstlendiklerini ileri sürmektedir. Bazı çalışmalarda ise öz yeterlik düzeyi yüksek olan öğretmenlerin öğrencilerin farklı ihtiyaçlarını karşılamaya çalıştıkları ve yeni öğretim stratejilerini uygulamaya yatkın oldukları (Tschannen-Moran, Hoy ve Hoy, 1998), yaratıcı iş davranışlarının arttı̆g (Hsiao, Chang, Tu ve Chen, 2011), yeni öğretim uygulamalarını daha fazla kullandıkları (Nie, Tan, Liau, Lau ve Chua, 2013), sorunlardan kaçınmak yerine bunları değiştirmek yönünde çaba göstermeyi tercih ettikleri ifade edilmektedir (Bandura, 1977). Balcı (2001), yüksek öz yeterliğe sahip öğretmenlerin sınıflarında öğrenmeyi ve girişimciliği teşvik eden bir ortam oluşturduklarını ve öğrencilerin öğrenme ihtiyaçlarının karşılanması noktasında daha hassas davrandıklarını ileri sürmektedir. Ayrıca, Gorozidis ve Papaioannou (2011) öz yeterliği yüksek öğretmenlerin değişime uyum sağlama, değişimi uygulama ve yeniklikçi fikirler üretme noktasında daha başarılı olduklarını ve bir bütün olarak değişimin başarılı olmasında önemli bir rol oynadıklarını belirtmektedir. Bu noktada, okulda değişim sürecinin etkili bir şekilde yönetilebilmesi ve olumlu sonuçlar doğurabilmesi bağlamında öğretmen öz yeterliğinin önemli bir değişken olabileceği düşünülmektedir.

\section{Öğretmenlerin Değişime Direnci}

Değişimin örgütlerin yapı, işleyiş veya süreç bakımından planlı ya da ani bir biçimde farklılaşmasına neden olduğu düşünüldüğünde, çalışanların değişime karşı mesafeli ve endişeli olmalarının doğal olduğu öne sürülebilir. Değişime direnç bu bakımdan değişim yönetiminin bir aşamasını ya da sonucunu değil, kendi başına bir olguyu ifade etmektedir (Woodman ve Dewett, 2004). Nickerson (2010), örgütsel değişimin getirdiği belirsizlik ortamının çalışanlarda panik yaratmasının, değişime direncin önemli bir sebebi olabileceğini belirtmektedir. Örgütlerde değişime direncin olası sebeplerini inceleyen Dawson (2003), yapılan işin niteliğinin değişmesi, ekonomik gelirin azalması, psikolojik tehditler, mevcut sosyal ilişkilerin bozulması ve statü kaybı gibi endişelerle çalışanların değişime direnç 
gösterebileceğini ifade etmektedir. Öte yandan, örgüt geliştirme ve örgütsel değişim yaklaşımlarında değişime direnci yok sayma veya ortadan kaldırma eğilimini görmek mümkündür. $\mathrm{Bu}$ bağlamda değişime direncin, alanyazında genellikle üstesinden gelmek (overcome) kavramıla birlikte kullanıldığını görmek mümkündür (Coch ve French, 1948; Geller, 2003; Warrick, 2010). Örgüt alanyazınında negatif psikolojiye karşı son yıllarda önem kazanan pozitif psikoloji yaklaşımının ortaya koyduğu kavramlar açısından bakıldığında, değişime direnç örgüt için bir tehdit değil, aksine fırsat olarak görülebilir (Bouckenooghe, 2009). Değişime direnen çalışanların, uygulamaya dönük yapıcı fikirleri olabileceği gibi dikkate alınmamaları halinde değişimin önünde önemli bir engel olarak yer alabilecekleri düşünülebilir (Hargreaves ve Fullan,1998).

Eğitimde değişimi gerçekleştirmek, planlama aşamasında teknik olarak kolay görünse de, sosyal bir uygulama alanı olduğundan oldukça karmaşık ve zor bir süreçtir (Fullan, 2007). Toplumun çeşitli kesimlerinin ve baskı gruplarının eğitiminden talep ve beklentileri bir yana okulun kendisi, değişimin uygulanmasını doğrudan etkileyecek birçok değişkeni içerisinde barındırmaktadır. Bu bağlamda, öğretmenlerin değişime karşı tutumlarının, değişimin başarılı olmasında önemli bir rolü olduğu söylenebilir. Öğretmenlerin değişime karşı olumlu duygu ve düşüncelere sahip olmaları, değişimin uygulanmasına destek vermeleri açısından oldukça önemlidir (Fullan, 2007; Hargreaves, 1998; Harris, 2002). Bunun aksine öğretmenlerin, değişime karşı olumsuz tutumlar içerisinde olmaları ve değişime direnç göstermelerinin bütün eğitim sistemini ilgilendiren önemli değişimlerin başarısı açısından olumsuz bir etkiye sahip olduğu düşünülebilir.

Öğretmenlerin değişime direnmelerinde etkili olan bazı faktörlerden söz edilebilir. Öğretmenler iyi bildikleri yöntemleri kullanmaya, bir anlamda alışkanlıklarını devam ettirmeye yönelik bir eğilim içinde olabilirler (Greenberg ve Baron, 2000). Bunun yanında, meslektaşlarıyla genellikle güçlü ilişkiler kuran öğretmenlerin, değişime şüpheyle yaklaşmaları ve okulda mevcut olan kurulu düzenin bozulmasını bir tehdit olarak algılamaları beklenebilir. Daly (2010), değişimin başarılı olması için öğretmenlerin güvendikleri meslektaşlarından etkilenebileceğini ve bu şekilde öğrenmelerinin daha kolay olabileceğini vurgulamaktadır. Bu bağlamda, değişimin etki alanını artırmak için okulun sosyal sermayesine odaklanmak yerinde bir yaklaşım olarak değerlendirilebilir.

Değişime direnç, çalışanların değişimin gerekliliğine inanmaması, değişimin kendilerine ve örgüte zarar getireceğini düşünmeleri ve değişime ilişkin olumsuz duygular taşımaları olarak ifade edilmektedir (Piderit, 2000). Oreg (2006) değişime direnci duyuşsal, bilişsel ve davranışsal olmak üzere 
üç boyutta ele almaktadır. Değişime direncin duyuşsal boyutunda, çalışanların örgütsel değişime ilişkin duyguları; davranışsal boyutunda, çalışanların örgüt içerinde değişime karşı geliştirdikleri davranışları ve son olarak bilişsel boyutunda ise çalışanların değişime ilişkin mevcut inançları ele alınmaktadır.

\section{Öğretmen Öz Yeterliği}

Öz yeterlik, insanların hayatlarını ve hayatlarında gerçekleşen olayları kontrol etmeleri için bilişsel ve duyuşsal kaynaklarını harekete geçirebilme yeteneklerine olan inançları olarak ifade edilmektedir (Wood ve Bandura, 1989). Lewandowski (2005) daha basit bir biçimde öz yeterliğii, bireyin bir işi ya da eylemi başarıyla gerçekleştirebilmesi ya da önceden belirlenen bir hedefe ulaşabilmeye dönük yeteneği olduğuna yönelik inancı olarak nitelendirmektedir. Son yıllarda öz yeterliğin, öğretmenlerin davranışlarının ve etkililiklerinin daha iyi anlaşılması bağlamında çalışmalara konu edildiği görülmektedir (Bitto ve Butler, 2010; Cagle ve Hopkins, 2009; Demir, 2008; Domsch, 2009; Garcia, 2004; Gençtürk ve Memiş, 2010; Guskey ve Passaro, 1993; Hoy, 2000; Kurt, 2009; Lewandowski, 2005; Ross ve Gray, 2006; Tschannen-Moran ve Hoy, 2001, 2007; Usher ve Pajares, 2008; Yilmaz ve Çokluk-Bökeoğlu, 2008).

Öğretmen öz yeterliğiyle ilgili araştırmalar incelendiğinde, öğretmen öz yeterliğinin okul müdürünün liderlik stiliyle (Griffin, 2009; Kurt, 2009), öğretmenlerin örgütsel vatandaşlık davranışlarıyla (Yücel, Yalçın ve Ay, 2009), öğretmenlerin tükenmişlik düzeyleriyle (Brouwers ve Tomic, 2000; Evers ve diğ., 2002), stres yaşama düzeyleriyle (Schwarzer ve Hallum, 2008) ve öğrenci başarısıyla (Goddart, Hoy ve Hoy, 2000; Ross, 1992) ilişkilendirildiği görülmektedir. Öğretmen öz yeterliği, öğretmenin öğretim sürecinde başarılı olması ve tüm öğrencilerin öğrenmesini olumlu yönde etkileyebilmesi olarak ifade edilmektedir (Tschannen-Moran ve Hoy, 2001). Buna göre öğretmenin öğrenci başarısına olumlu yönde etki edebileceğine yönelik inancı, algılanan öz yeterlik inancını artırırken tersi durumda öğretmenin öz yeterliğinin düşmesi beklenmektedir. Ross ve Gray (2006) öz yeterliği yüksek öğretmenlerin öğretimi geliştirmek için yoğun çaba harcadıklarını ve öğrenci öğrenmesine yönelik en iyi uygulamaları geliştirip sınıfta kullanma eğiliminde olduklarını ifade etmektedir. Caprara, Barbaranelli, Steca ve Malone (2006) öz yeterlik düzeyi yüksek olan öğretmenlerin öğretim stratejilerini daha etkili bir biçimde kullandığını, öğrencilerin derse daha fazla katılımını sağladığını ve sınıf yönetimi becerilerinin daha yüksek olduğunu belirtmektedir. 
$\mathrm{Bu}$ araştırmada öğretmenlerin değişime direnme davranışları ile öz yeterlikleri arasındaki ilişkiler incelenmiştir. Ayrıca öğretmenlerin öz yeterlik düzeylerinin değişime direnme davranışları üzerindeki yordacılık gücü irdelenmiştir. Mevcut araştırmadan elde edilecek bulguların öğretmenlerin değişime direnme davranışlarının daha detaylı bir biçimde çözümlenmesi bağlamında önemli görülebileceği düşünülmektedir.

\section{Yöntem}

\section{Araștırmanın Modeli}

$\mathrm{Bu}$ araştırma ilişkisel tarama modelinde kurgulanmıştır. Araştırma kapsamında ilköğretim okullarında görev yapan öğretmenlerin değişime direnme davranışları ile öz yeterlik düzeyleri arasındaki ilişkiler ve öğretmenlerinin öz yeterlik düzeyinin değişime direnme davranışları üzerindeki yordayıcılık gücü incelenmiştir.

\section{Evren ve Örneklem}

Araştırmanın evrenini Ankara il merkezinde bulunan ilköğretim okullarında görevli öğretmenler oluşturmaktadır. Bu evrenden basit seçkisiz örnekleme yoluyla 14 ilköğretim okulundan seçilen toplam 415 öğretmen araştırmaya katılmıştır. Bu öğretmenlerin 217'si (\%52.3) erkek, 198'i (\%47.7) kadındır. Araştırmaya katılan öğretmenlerden 162'si (\%39) sınıf öğretmeni, 253'ü (\%61) branş öğretmeni olarak görev yapmaktadır. Araştırmaya katılan öğretmenlerin mesleki kıdemleri incelendiğinde, kıdeminin 1-42 yıl arasında değiştiği ve ortalama kıdem yılının 13 olduğu bulunmuştur.

\section{Veri Toplama Araçları}

Değişime Direnme Ölçeği: Bu ölçek Oreg (2006) tarafından geliştirilmiş, Güçlü, Özer, Kurt ve Kandemir (2010) tarafından Türkçeye uyarlanmıştır. Ölçek, Likert tipindedir ve 0-4 arasında puanlanmaktadır. Ölçek maddeleri " 0 = hiçbir zaman" ve " $4=$ her zaman" biçiminde derecelendirilmiştir. Ölçekte iş görenlerin değişime direnme tutumlarını belirlemeye yönelik dört alt boyutta (rutini arama, duygusal tepki, kısa vadeli düşünme ve bilişsel katılık) toplam 17 madde bulunmaktadır. Güçlü ve diğerleri (2010) tarafından yapılan faktör analizinde ölçeğin tek faktörlü bir yapıya sahip olduğu bulunmuştur. Tek faktör tarafından açılanan varyans \%46.98 (öz değer: 5.305) olarak hesaplanmıştır. Ayrıca ölçeğin iç tutarlık katsayısı .85 olarak bulunmuştur.

Mevcut çalışma kapsamında yapılan açımlayıcı faktör analizi sonucu ölçekteki maddelerin tek faktör altında toplandığı belirlenmiştir. Faktör yük değerleri .30 'un altında olan ve birden fazla faktöre girip aralarında faktör yük değer farkları .10 ve daha az olan 4 madde ölçekten çıkarılmıştır. Kalan 13 maddeyle analizlere devam edilmiş ve nihai analizi sonucunda ölçeğin 
tek faktör altında toplandığ görülmüştür. Bu sonucun, Güçlü ve diğerleri (2010) tarafından ölçeğin geçerliğine yönelik elde edilen sonuçla örtüştüğü söylenebilir. 13 maddeden oluşan ölçeğin faktör yük değerleri .33 ile .67 arasında değişmektedir. Ölçekteki maddeler varyansın \%29.45'ini açıklamaktadır. Ayrıca tek faktörlü bir yapı arz eden ölçeğin iç tutarlık katsayısı .95 olarak hesaplanmıştır. Bu bağlamda, ölçeğin yapılan geçerlik ve güvenirlik analizleri Değişime Direnme Ölçeği'nin alanda kullanılabilecek geçerli ve güvenilir bir ölçek olduğunu göstermiştir.

Öğretmen Öz Yeterlik Ölçeği: Öğretmen Öz Yeterlik Ölçeği (Teacher's Sense of Efficacy Scale-TSES) Tschannen-Moran ve Hoy (2001) tarafından geliştirilmiştir. Ölçeğin Türkçeye Uyarlaması Çapa, Çakıroğlu ve Sarıkaya (2005) tarafından yapılmıştır. Ölçek, “öğrenci katılımına yönelik öz yeterlilik (8 madde)", "öğretim stratejilerini kullanmaya yönelik öz yeterlik (8 madde)" ve "sınıf yönetimine yönelik öz yeterlik (8 madde)" olmak üzere üç faktörde toplam 24 maddeden oluşmaktadır. 9'lu Likert tipi bu ölçekte maddeler " 1 = yetersiz" ve " 9 = yeterli" şeklinde derecelendirilmiştir. Ölçeğin Türkçeye uyarlanması amacıyla Türkiye'deki 6 üniversitenin Eğitim Fakültelerinde öğrenim görmekte olan 628 öğrenciden oluşan bir örneklem ile veri toplanmıştır. Toplanan veriler Doğrulayıcı Faktör Analizine tabi tutulmuştur. Analiz sonucunda TLI ve CFI değerleri .95 'ten yüksek bulunmuş, RMSEA değeri .065 olarak bulunmuştur. Bu değerler modelin fit ettiğini ortaya koymaktadır. Ölçeğin alt boyutlarına ait Cronbach's Alpha güvenilirlik katsayıları ögrenci katılımına yönelik öz yeterlilik boyutunda .82; öğretim stratejilerini kullanmaya yönelik öz yeterlik boyutunda .86 ve sinıf yönetimine yönelik öz yeterlik boyutunda .84 'tür (Çapa ve diğ., 2005).

$\mathrm{Bu}$ çalı̧̧mada yapılan açımlayıcı faktör analizi sonucu ölçekteki maddelerin 3 faktör altında toplandığı belirlenmiştir. Faktör yük değerleri .30'un altında olan ve birden fazla faktöre girip aralarında faktör yük değer farkları .10 ve daha az olan 2 madde ölçekten çıkarılmıştır. Kalan 22 maddeyle analize devam edilmiş ve nihai analiz sonucunda maddelerin 3 faktörde toplandığı görülmüştür. Üç faktör birlikte toplam varyansın $\% 60.07$ 'sini açıklamaktadır. Buna göre, sınıf yönetimi boyutu 6 maddeden oluşmakta ve faktör yük değerleri .54 ile .81 arasında değişmektedir. Bu boyut varyansın \%48.29'unu açıklamaktadır. Öğretim stratejileri boyutu 8 maddeden oluşmakta ve faktör yük değerleri .46 ile .71 arasında değişmektedir. Bu boyutun açıkladığı varyans \%6.57'dir. Son olarak, öğrenci katılımı boyutu 8 maddeden oluşmakta ve faktör yük değerleri .56 ile .72 arasında değişmektedir. Bu boyutun açıkladığı varyans ise \%5.21'dir. Ayrıca ölçeğin güvenirliğini tespit etmek amaciyla Cronbach's Alpha katsayısı hesaplanmıştır. Ölçeğin 3 alt boyutu için de Cronbach's Alpha değeri 89 
Uşak Üniversitesi Sosyal Bilimler Dergisi

$2013,6 / 4$

T. ÇALIK, S. KOŞAR, A. Ç. KILINÇ, E. ER

olarak hesaplanmıştır. Tüm ölçek için ise Cronbach's Alpha katsayısı .95 olarak hesaplanmıştır.

\section{Verilerin Analizi}

Verilerin analizinde SPSS 15.0 programı kullanılmıştır. Verilerin analizi temel olarak iki adımda gerçekleştirilmiştir. Birinci adımda veri setinde bulunan eksik ya da hatalı veriler incelenmiş ve EM algoritması yoluyla eksik değerlere atama yapılmıştır. Değişime direnme ile öğretmen öz yeterliğinin alt boyutları arasındaki ilişkilerin belirlenmesinde Pearson Momentler Çarpımı Korelasyon Katsayısı $(r)$ hesaplanmıştır. Ayrıca değişime direnmenin, öğretmen öz yeterliğinin alt boyutları tarafından yordanmasına ilişkin analizlerde çoklu doğrusal regresyon analizi uygulanmıştır. Regresyon analizinin yorumlanmasında standartlaştırılmış Beta $(\beta)$ katsayısı ve bunun anlamlılığına ilişkin t-testi sonuçları dikkate alınmıştır.

\section{Bulgular}

\section{Öğretmenlerin Değişime Direnme Düzeyleri ile Öz Yeterlikleri Arasındaki İlişki}

Araştırmaya katılan ilköğretim okulu öğretmenlerinin değişime direnme ve öz yeterlik düzeylerine ilişkin ortalama ve standart sapma değerleri ve öğretmenlerin değişime direnme düzeyleri ile öz yeterlikleri arasındaki ilişkiler için Pearson Momentler Çarpımı Korelasyon katsayıları Tablo 1'de verilmiştir.

Tablo 1 incelendiğinde, değişime direnme ile öz yeterliğin öğrenci katılımı $(r=-.18, p<.01)$, sinıf yönetimi $(r=-.13, p<.01)$ ve öğretim stratejileri $(r=-.17, p<.01)$ boyutları arasında düşük düzeyde negatif yönlü anlamlı ilişkilerin olduğu görülmektedir. Bununla birlikte, öz yeterliğin öğrenci katılımı ve sınıf yönetimi $(r=.69, p<.01)$, öğrenci katılımı ve öğretim stratejileri $(r=.78, p<.01)$ ve sınıf yönetimi ve öğretim stratejileri $(r=.72, p$ $<.01)$ alt boyutları arasında pozitif yönlü anlamlı ilişkiler bulunmuştur. Başka bir deyişle, öğretmenlerin öz yeterliğin alt boyutlarına ilişkin algılarının birlikte azalıp birlikte artarken, değişime direnme düzeyleri ve öz yeterlik düzeyleri arasında ters yönde bir ilişkinin varlığından söz edilebilir.

Tablo 1: Değiş̧kenlerin Aritmetik Ortalama ve Standart Sapma Değerleri ile Değişkenler Arası Korelasyonlar $(n=415)$

\begin{tabular}{lllllll}
\hline Değişkenler & $\bar{X}$ & $S$ & 1 & 2 & 3 & 4 \\
\hline
\end{tabular}


Uşak Üniversitesi Sosyal Bilimler Dergisi

$2013,6 / 4$

T. ÇALIK, S. KOŞAR, A. Ç. KILINÇ, E. ER

\begin{tabular}{lrrrccc}
\hline 1. Değişime Direnç & 2.69 & .47 & - & $-.18^{* *}$ & $-.13^{* *}$ & $-.17^{* *}$ \\
2. Öğrenci Katılımı & 6.44 & 1.11 & & - & $.69^{* *}$ & $.78^{* *}$ \\
3. Sı̈nf Yönetimi & 6.89 & 1.04 & & & - & $.72^{* *}$ \\
4. Öğretim Stratejileri & 6.84 & 1.09 & & & & - \\
\hline
\end{tabular}

${ }^{* *} p<.01 ;{ }^{*} p<.05$

Öğretmenlerin Değişime Direnme Düzeylerinin Yordanması

İlköğretim okulu öğretmenlerinin değişime direnme düzeylerinin yordanmasına ilişkin çoklu doğrusal regresyon analizi sonuçları Tablo 2'de verilmiştir.

Tablo 2: Değişime Direnmenin Yordanmasına İlişkin Regresyon Analizi Sonuçlarn

\begin{tabular}{lccccc}
\hline Değişkenler & $B$ & $S h$ & $\beta$ & $t$ & $p$ \\
\hline Sabit & 3.220 & .183 & & 17.577 & .00 \\
Öğrenci Katılımı & -.058 & .040 & -.12 & -1.458 & .15 \\
Öğretim Stratejileri & -.054 & .044 & -.10 & -1.216 & .23 \\
Sinıf Yönetimi & .013 & .034 & .03 & .376 & .71 \\
\hline
\end{tabular}

$R=.19 R^{2}=.04$

$F_{(3-411)}=4.961, p=.002$

Tablo 2 incelendiğinde, öğretmen öz yeterliğinin öğrenci katılımı, öğretim stratejileri ve sınıf yönetimi boyutları birlikte değişime direnme ile anlamlı ilişkiler vermiştir $\left(R=.19, R^{2}=.04, p<.01\right)$. Adı geçen üç değişken birlikte, çalışanlara duyarlılık boyutunda toplam varyansın yaklaşık \% $\%$ 'ünü açıklamaktadır. Regresyon analizi sonuçlarına göre, öğretmen öz yeterliğinin öğrenci katılımı $(\beta=-.12, p>.05)$, öğretim stratejileri $(\beta=-.10, p$ $>.05)$ ve sınıf yönetimi $(\beta=-.03, p>.05)$ alt boyutlarının değişime direnmenin anlamlı yordayıcıları olmadığı görülmektedir. Başka bir ifadeyle, değişime direnmenin öğretmen öz yeterliğinin alt boyutları tarafından yordanmasına ilişkin kurulan modelin anlamlı ilişkiler ortaya koymasına rağmen, öz yeterliğin alt boyutlarından hiç birinin değişime direnmenin anlamlı bir yordayıcısı olmadığı belirlenmiştir.

\section{Tartışma, Sonuç ve Öneriler}

Bu araştırmada ilk olarak öğretmenlerin değişime direnme düzeyleri ile öz yeterlikleri arasındaki ilişki incelenmiştir. Araştırma sonuçları öz yeterliğin öğrenci katılımı, öğretim stratejileri ve sınıf yönetimi alt boyutlarının değişime direnme ile düşük düzeyde olumsuz yönde anlamlı ilişkiler içinde olduğunu göstermektedir. Başka bir ifadeyle, araştırma 
sonuçlarından öğretmenlerin öz yeterlik düzeyleri arttıkça değişime daha az direnç gösterdikleri anlaşılmaktadır. Bu bulgu Ghaith ve Yaghi'nin (1997) araştırma bulguları ile benzerlik göstermektedir. İlgili alanyazın incelendiğinde, öz yeterliği yüksek olan öğretmenlerin yeni fikirlere daha açık oldukları (Jerald, 2007), değişimi benimseme konusunda daha istekli oldukları (Allinder, 1994; Akt. Tschannen-Moran ve Hoy, 2001), yeni öğretim stratejilerini uygulamaya daha yatkın oldukları (Tschannen-Moran, Hoy ve Hoy, 1998), sınıflarında öğrenmeyi ve girişimciliği teşvik eden bir ortam oluşturma noktasında daha etkili oldukları (Balcı, 2001) ve değişime daha kolay uyum sağladıklarının (Gorozidis ve Papaioannou, 2011) ortaya konduğu görülmektedir. Töremen (2002) eğitimde değişim sürecinin önemli engellerinden birinin öğretmenlerin değişime yönelik olumsuz inançları olduğunu, ekonomik ve sosyal kayıp yaşama kaygısının öğretmenlerin değişime direnmelerine neden olduğunu ileri sürmektedir. Varank ve Tozoğlu (2006) ise öğretmenlerin öz yeterlik düzeylerinin yüksek olmasının yaşadıkları kaygının düzeyini azaltabileceğini vurgulamaktadır. Bu bağlamda, araştırmanın öğretmenlerin değişime direnme davranışları ile öz yeterlik düzeyleri arasında negatif yönde anlamlı ilişkiler olduğunu gösteren bulgusunun ilgili alanyazınla ve beklentilerle uyumlu olduğu söylenebilir.

Araştırmada öğretmenlerin öz yeterlik düzeylerinin değişime direnme davranışları üzerindeki yordayıcılık gücü incelenmiştir. Araştırma sonuçları öz yeterliğin değişime direnme üzerindeki yordayıcılık gücünü irdelemek amaciyla kurulan regresyon modelinin anlamlı sonuçlar vermesine rağmen öz yeterliğin alt boyutlarının değişime direnmenin anlamlı yordayıcısı olmadığını göstermektedir. Bu bulgu öğretmenlerin değişime direnme davranışları sergilemelerine yol açan farklı etmenlerin olduğu biçiminde yorumlanabilir. Lee, Cawthon ve Dawson (2013) öğretmen öz yeterliğinin öğretmenlerin öğretime yönelik geliştirdikleri bakış açılarıyla olan ilişkisini incelendikleri araştırmalarında öğretmenlerin öz yeterliklerini artırmaya odaklanmanın, öğretime yönelik sahip oldukları bakış açılarını değiştirme noktasında izlenecek öncelikli yollardan biri olmayabileceğini ortaya koymuşlardır. Bu ifade ile araştırma bulgularının kısmen örtüştügü ileri sürülebilir. Öte yandan, araştırmanın bu bulgusunun benzer başka araştırmaların bulgularıyla çeliştiği görülmektedir (Hsiao ve diğ., 2011; Nie ve diğ., 2013). Öz yeterliğin bireylerin karşılaştıkları zorlayıcı durumlara yönelik tutumlarında oldukça önemli bir etken olduğunu bildiren Bandura (1977), öz yeterliği yüksek olan öğretmenlerin olumsuz durumlarla mücadele etmekten kaçınmadıklarını, başarısızlıktan yılmadıklarını, başarısızlı̆̆ın nedenlerini bilgi ve beceri eksikliğini 
bağladıklarını ve öğretimde yenilik yapma noktasında istekli davrandıklarını ileri sürmektedir. Bu bağlamda, araştırmada öz yeterliğinin öğrenci katılımı, öğretim stratejileri ve sınıf yönetimi alt boyutlarının öğretmenlerin değişime direnme davranışlarının anlamlı bir şekilde yordamamasının beklentilerle uyumlu olmadığını söylemek mümkündür.

Araştırma sonuçları öğretmen öz yeterliğinin öğretmenlerin değişime direnme davranışlarının anlamlı bir yordayıcısı olmadığını göstermekle birlikte, alanyazında bu konuda farklı bulgulara ulaşan araştırmaların olduğu görülmektedir. Bu bağlamda, öğretmenlerin değişime direnme davranışlarının öz yeterlik düzeyleriyle ilişkisini farklı eğitim kademlerinde ve farklı araştırma yöntemleri kullanılarak inceleyen araştırmalar yapılabilir. Bununla birlikte, öğretmenlerin değişime direnmelerine neden olan farklı etmenlerin de olabileceği düşünülmektedir. Değişim planlaması yapılırken, öğretmenlerin mevcut yeterliğini dikkate almak ve okulu merkeze alan bir değişim stratejisi belirlemenin, eldeki insan kaynağının verimli kullanılması ve değişimin benimsenmesi açısından olumlu etkiler yapacağı beklenebilir. Bu noktada öğretmenlerin değişime direnme nedenlerini ortaya koyan ve bunu örgütsel ve kişisel faktörlerle ilişkilendiren başka çalışmaların yapılmasının alanyazına önemli katkı sunabileceği düşünülmektedir. Ayrıca, çalışmada kullanılan ölçeğin farklı bir dil ve kültürden Türkçeye uyarlandığ düşünüldüğünde, öğretmenlerin değişime yönelik görüşlerini ortaya koymayı amaçlayan Türk kültürüne özgü ölçek geliştirme çalışmalarının yapılabileceği düşünülmektedir.

\section{Kaynakça}

Akpınar, B. ve Aydın, K. (2007). Eğitimde değişim ve öğretmenlerin değişim algıları. Eğitim ve Bilim, 32(144), 71-80.

Balc1, A. (2001). Etkili okul ve okul geliştirme. Ankara: Pegem A.

Bandura, A. (1977). Self-efficacy: Toward a unifying theory of behavioral change. Psychological Review, 84(2), 191-215.

Banning, E. I. (1954). Teachers attitudes toward curriculum change: The effect of personal relationships on the degree of favorableness. The Journal of Experimental Education 23(2), 133-147.

Bitto, L., \& Butler, S. (2010). Math teacher self-efficacy and its relationship to teacher effectiveness. Journal of Cross-Disciplinary Perspectives in Education, 3(1), 40-45.

Bouckenooghe, D. (2009). What is crucial in developing a positive attitude toward change? The role of content, context, process and individual variables in understanding readiness for change (Yayımlanmamış doktora tezi). Ghent

University. 
Uşak Üniversitesi Sosyal Bilimler Dergisi

$2013,6 / 4$

T. ÇALIK, S. KOŞAR, A. Ç. KILINÇ, E. ER

http://lib.ugent.be/fulltxt/RUG01/001/308/921/RUG01-

001308921_2010_0001_AC.pdf adresinden 10.03.2013 tarihinde

erişim sağlanmıştır.

Brouwers, A., \& Tomic, W. (2000). A longitudinal study of teacher burnout and perceived self-efficacy in classroom management. Teaching and Teacher Education, 16(2), 239-253.

Burnes, B. (2009). Managing change. Essex: Pearson.

Cagle, K., \& Hopkins, P. (2009). Teacher self-efficacy and the supervision of marginal teachers. Journal of Cross-Disciplinary Perspectives in Education, 2(1), 25-31.

Caprara, G. V., Barbaranelli, C., Steca, P., \& Malone, P. S. (2006). Teacher s elf-efficacy beliefs as determinants of job satisfaction and students' academic achievement: A study at the school level. Journal of school Psychology, 44, 473-490.

Cenker, B. ve Akgül-Macaroğlu, E. (2011). İlköğretim okullarında görev yapan öğretmenlerin okulda değişim yönetiminin gerçekleştirilmesine bakış açılarının değerlendirilmesi. Sakarya Üniversitesi Journal of Education, 1(1), 26-31.

Coch, L., \& French, J. R. P., Jr. (1948). Overcoming resistance to change. Human Relations, 1(4), 512-532.

Çapa, Y., Çakıroğlu, J. ve Sarıkaya, H. (2005). Öğretmenlik özyeterlik ölçeği Türkçe uyarlamasının geçerlik ve güvenirlik çalışması. Ĕ̆itim ve Bilim, 30(137), 74-81.

Daly, A. (2010). Mapping the terrain. In A. Daly. (Ed.), Social network theory and educational change (pp. 1-16). Cambridge: Harvard Education.

Dawson, P. (2003). Understanding organizational change: The contemporary experience of people at work. London: Sage.

Demir, K. (2008). Transformational leadership and collective efficacy: The moderating roles of collaborative culture and teachers' self-efficacy. Eurasian Journal of Educational Research, 33, 93-112.

Domsch, G. D. (2009). A study investigating relationships between elementary principals' and teachers' self-efficacy and student achievement. Retrieved from ProQuest Dissertations and Thesis database. (UMI No. 3383305)

Evers, W. J. G., Brouwers, A., \& Tomic, W. (2002). Burnout and self-efficacy: A study on teachers' beliefs when implementing an innovative educational system in the Netherlands. British Journal of Educational Psychology, 72(2), 227-243.

Floyd, P. (2002). Organizational change. Oxford: Capstone. 
Fullan, M. (1993). Why teachers must be change agents. Educational Leadership, 50(6), 12-17.

Fullan, M. (2007). The new meaning of educational change. Amsterdam: Teachers College.

Garcia, D. C. (2004). Exploring connections between the construct of teacher efficacy and family involvement practices: Implications for urban teacher preparation. Urban Education, 39(3), 290-315.

Geller, E. S. (2003). Leadership to overcome resistance to change. Journal of Organizational Behavior Management, 22(3), 29-49.

Gençtürk, A. ve Memiş, A. (2010). İlköğretim okulu öğretmenlerinin özyeterlik algıları ve iş doyumlarının demografik faktörler açısından incelenmesi. İlköğretim Online, 9(3), 1037-1054.

Ghaith, G., \& Yaghi, H. (1997). Relationships among experience, teacher efficacy, and attitudes toward the implementation of instructional innovation. Teaching and Teacher Education, 13(4), 451-458.

Goddart, R. D., Hoy, W. K., \& Hoy, A. W. (2000). Collective teacher efficacy: Its meaning, measure, and impact on student achievement. American Educational Research Journal, 37(2), 479-507.

Gorozidis, G., \& Papioannou, A (2011). Teachers' self efficacy, achievement goals, attitudes and intentions to implement the new Greek physical education curriculum. European Physical Education Review, 17(2), 231253.

Greenberg, J., \& Baron, R. A. (2000). Behavior in organizations. Upper Saddle River, NJ: Prentice Hall.

Griffin, K. L. (2009). The relationship between self-efficacy of teachers and their perception of the school principal's leadership style. Retrieved from ProQuest Dissertations and Thesis database. (UMI No. 3374149)

Guskey, T. R. (1987). Context variables that affect measures of teacher efficacy. Journal of Educational Research, 81(1), 41-47.

Guskey, T. R., \& Passaro, P. (1993). Teacher efficacy: A study of construct dimensions. Paper presented at the annual meeting of the American Educational Research Education. (Atlanta, GA, April 11-16, 1993).

Güçlü, N., Özer, A., Kurt, T. ve Kandemir, M. (2010). Öğretmenlerin yeni ilköğretim programına ilişkin tutumlarının, epistemolojik inançlarına ve değişime direnme tutumlarına dayalı olarak yordanması. V. Ulusal Eğitim Yönetimi Kongresi, 1-2 Mayıs 2010, Antalya.

Hargreaves, A. (1998). Changing teachers changing times: Teachers work and culture in the postmodern age. London: Cassel. 
Hargreaves, A. (2005). Educational change takes ages: Life, career and generational factors in teachers' emotional responses to educational change. Teaching and Teacher Education 21(8), 967-983.

Hargreaves, A., \& Fullan, M. (1998). What's worth fighting for out there. Toronto: Teachers' College.

Harris, A. (2002). School improvement: What is in it for schools? London: Routledge Falmer.

Hopkins, D. (2007). Every school a great school: Realizing the potential of system leadership. Berkshire: Open University.

Hoy, A. W. (2000). Changes in teacher efficacy during the early years of teaching. Paper presented at the annual meeting of the American Educational Research Association, New Orleans, LA. Session 43:22, Qualitative and Quantitative Approaches to Examining Efficacy in Teaching and Learning, April 28.

Hsiao, H. C., Chang, J. C., Tu, Y. L., \& Chen, S. C. (2011). The impact of selfefficacy on innovative work behavior for teachers. International Journal of Social Science and Humanity, 11(1), 31-36.

Jerald, C. D. (2007). Believing and achieving (Issue Brief). Washington, DC: Center for Comprehensive School Reform and Improvement. http://www.eric.ed.gov/PDFS/E D495708. pdf adresinden 23.03.2013 tarihinde erişim sağlanmıştır.

Kennedy, C., \& Kennedy, J. (1996). Teacher attitudes and change implementation. System, 24(3), 351-360.

Kurt, T. (2009). Okul müdürlerinin dönüşümcü ve eylemci liderlik stilleri ile öğretmenlerin kolektif yeterliği ve öz yeterliği arasındaki ilişkilerin incelenmesi (Yayımlanmamış doktora tezi). Gazi Üniversitesi, Ankara.

Lee, B., Cawthon, S., \& Dawson, K. (2013). Elementary and secondary teacher self-efficacy for teaching and pedagogical conceptual change in a drama-based professional development program. Teaching and Teacher Education, 30, 84-98.

Lewandowski, K. H. (2005). A study of the relationship of teachers' self-efficacy and the impact of leadership and professional development (Doctoral dissertation). Retrieved from ProQuest Dissertations and Thesis database. (UMI No. 3164695)

Nickerson, J. (2010). Leading change in web 2.1 world. Washington: Brookings Institution.

Nie, Y., Tan, G. H., Liau, A. K., Lau, S., \& Chua, B. L. (2013). The roles of teacher efficacy in instructional innovation: Its predictive relations to constructivist and didactic instruction. Educational Research for Policy and Practice, 12(1), 67-77. 
Oreg, S. (2006). Personality, context and resistance to organizational change. European Journal of Work and Organizational Psychology, 15(1), 73-101.

Piderit, S. K. (2000). Rethinking resistance and recognizing ambivalence: A multi dimensional view of attitudes toward an organizational change. Academy of Management Review, 25(4), 783-794.

Ross, J. A. (1992). Teacher efficacy and the effects of coaching on student achievement. Canadian Journal of Education, 17(1), 51-65.

Ross, J. A., \& Gray, P. (2006). Transformational leadership and teacher commitment to organizational values: The mediating effects of collective teacher efficacy. School Effectiveness and School Improvement, 17(2), 179-199.

Schwarzer, R., \& Hallum, S. (2008). Perceived teacher self-efficacy as a predictor of job stress and burnout: Mediation analyses. Applied Psychology: An International Review, 57, 152-171.

Seashore, K. R. (2009). Leadership and change in schools: Personal reflections over the last 30 years. Journal of Educational Change, 10(23), $129-140$

Stickland, F. (1998). The dynamics of change: Insights into organisational transition from the natural world. London: Routledge.

Töremen, F. (2002). Eğitim örgütlerinde değişimin engel ve nedenleri. Firat Üniversitesi Sosyal Bilimler Dergisi, 12(1), 185-202.

Tschannen-Moran, M., \& Hoy, A. W. (2001). Teacher efficacy: Capturing and elusive construct. Teaching and Teacher Education, 17(7), 783-805.

Tschannen-Moran, M., \& Hoy, A. W. (2007). The differential antecedents of self-efficacy beliefs of novice and experienced teachers. Teaching and Teacher Education, 23(6), 944-956.

Tschannen-Moran, M., Hoy, A. W., \& Hoy, W. K. (1988). Teacher efficacy: Its meaning and measure. Review of Educational Research, 68, 202-248.

Usher, E. L., \& Pajares, F. (2008). Sources of self-efficacy in school: Critical review of the literature and future directions. Review of Educational Research, 78(4), 751-796.

Varank, I., \& Tozoglu, D. (2006). Why are teachers resistant to change? Key issues and challenges in technology integration. Afyon Kocatepe Üniversitesi Sosyal Bilimler Dergisi, 8(1), 193-207.

Warrick, D. D. (2010). Launch: Assessment, action planning, and implementation. In W. J. Rothwell, J. M. Stavros, R. Sullivian, \& A. Sullivian. (Eds.), Practicing organizational development: A guide for leading change (pp. 234-268). San Francisco: Wiley.

Wheatley, M. J. (2006). Leadership and the new science. California: BerrettKoehler. 
Wood, R., \& Bandura, A. (1989). Social cognitive theory of organizational management. Academy of Management Review, 14(3), 361-384.

Woodman, R. W., \& Dewett, T. (2004). Organizationally relevant journeys in individual change. In Marshall S. Poole, \& Andrew H. Van de Ven (Eds.), Handbook of organizational change and innovation (pp. 32-49). New York: Oxford University.

Yılmaz, K. ve Çokluk-Bökeoğlu, O. (2008). İlköğretim okulu öğretmenlerinin yeterlik inançları. Ankara Üniversitesi Ĕ̆itim Bilimleri Fakültesi Dergisi, 41(2), 143-167.

Yücel, C., Yalçın, M. ve Ay, B. (2009). Öğretmenlerin öz-yeterlikleri ve örgütsel vatandaşlık davranışı. Sosyal Bilimler Dergisi, 21, 221-235.

Zayim, M. (2010). Investigating the relationship between primary and secondary level public school teachers' readiness for change and perceived organizational trust (Yayımlanmamış yüksek lisans tezi). Ortadoğu Teknik Üniversitesi, Ankara.

Zimmerman, J. (2006). Why some teachers resist change and what principals can do about it. NASSP Bulletin, 90(3), 238-249. 